\title{
NOTE
}

\section{TEFRA'S RESPONSE TO SHORT-TERM ABUSES OF INSURANCE ANNUITY POLICIES}

INTRODUCTION

In modern times, Congress has tried repeatedly to allow and even to help taxpayers plan for their retirement through the use of tax-favored long-term investment vehicles. Once any plan receives tax-favored status, however, any short-term tax sheltering properties that it may have are ultimately discovered and exploited. This note offers annuity plans as a case in point, and examines congressional efforts to remedy these abuses. In part II, this note examines annuity policies and the tax shelters they provided to help taxpayers plan for their retirement, which were later abused for their tax-sheltering nature by short-term investors. Part III examines efforts by Congress to remedy such abuses and whether those remedies were sufficient to close the loopholes. Part IV concludes that loopholes for short-term investors still exist in the Internal Revenue Code and can be exploited by carefully drafted universal life insurance plans.

II

\section{Exploitation of Annuity Policies Under Pre-TEFRA Law}

Before the Tax Equity and Fiscal Responsibility Act of 1982 (TEFRA), ${ }^{2}$ Internal Revenue Code section $\mathbf{7 2}$ granted highly favorable tax treatment to annuity contracts. During the period between the time the policyholder paid the first premium and the annuity starting date, the annuity owner was not taxed on the earnings the insurance company accumulated on his paid-in premiums. Taxation of interest and other current earnings on a policyholder's investment in an insurance annuity was deferred until annuity payments were received or amounts characterized as income were withdrawn. When a policyholder received an annuity payment, a portion of that payment was taxed as ordinary income under an "exclusion ratio," computed to divide the payment into a portion intended to reflect the protected nontaxable return of investment in the contract and a portion intended to reflect the taxable growth of the investment. ${ }^{2}$

2. See I.R.C. 72(b) (Lawyers Co-op. 1984). 
A policyholder also received highly favorable tax treatment on withdrawals made before the annuity starting date. Amounts paid out under a contract before the annuity payments began, such as payments upon loans, partial surrender, or liquidation of a contract, were first treated as a return of the policyholder's capital. Such amounts were taxable as ordinary income only after, and to the extent that, all of the policyholder's investment in the contract, computed as the sum of all premiums paid, had been recovered. ${ }^{3}$ Additionally, there was no provision assessing a tax penalty for withdrawals or for surrenders effected before the annuity starting date or before the policyholder reached the age specified in the contract.

The legislative history of TEFRA reveals congressional dissatisfaction with the abuses of insurance annuity contracts. Such contracts had begun to manifest a radical departure from the policy considerations underlying the favorable tax treatment afforded insurance annuities under pre-TEFRA law. Traditionally, annuity contracts were regarded as safe and conservative, albeit low-yielding, investments purchased by individuals who wanted to provide for a steady source of income during their retirement and to insure themselves against the possibility of outliving their assets. Monies invested in such annuity plans were afforded favorable tax treatment as an incentive for people to avail themselves of the recognized legitimate advantages of annuity contracts and to provide themselves with income security during their mature years. ${ }^{4}$

In recent years, however, the uses of annuity contracts have reflected numerous abuses of the protections granted to such plans under the tax law, demonstrating a marked shift in the use of insurance annuities from provision for long-term security for retirement to ordinary investment purposes, the latter being undertaken in annuity form solely because of the favorable tax treatment afforded such contracts. Notably, investors began to take advantage of these policies by making tax-exempt withdrawals from their accounts before the starting date of the policy. Congressional hearings revealed that the insurance industry had been actively marketing annuity contracts as a mechanism for obtaining favorable tax treatment by emphasizing the benefits of the tax deferral during the accumulation period, the tax-favored treatment of partial surrenders, and options for lump-sum settlements. ${ }^{5}$ While it has been commonly understood that the notions of tax shelters and protective devices for long-term economic security are properly linked, tax-favored status has been granted to the latter specifically for the purpose of protecting retirement income. ${ }^{6}$ Congress has manifested a willingness to endorse tax shelters for annuity and insurance policies to the extent that they serve the long-term goals of providing individuals with a

3. See id. \& 72(e).

4. See S. Rep. No. 494, 97th Cong., 2d Sess. 350, reprinted in 1982 U.S. Code Cong. \& Ad. News $781,1085$.

5. See id.

6. See S. Rep. No. 494, 97th Cong., 2d Sess. at 350, reprinted in 1982 U.S. Code Cong. \& Ad. News at 1087. 
source of income for their retirement years or the equally laudable end of protecting family members in the event of the death of the policyholder.7 What was objectionable about many of the pre-TEFRA policies was that they were being tied to relatively small amounts of insurance protection or retirement provisions solely to get tax-free build-up. In effect, plans that were orginally intended to serve as protective devices for long-term economic security were advertised, and increasingly used by policyholders, as shortterm investments to exploit their tax-sheltered status. ${ }^{8}$

\section{III}

\section{TEFRA}

\section{A. Rationale Behind the Law}

The legislative history of TEFRA indicates that Congress enacted it with two intentions. First, and specifically with regard to annuity plans, Congress was clearly concerned with escalating use of such plans as tax shelters and sought to remedy these abuses. To address this issue, Congress placed a renewed emphasis on the employment of annuities as a tax-sheltered mechanism only to the extent that they provide for long-range savings for retirement security. In approving the TEFRA provisions limiting the tax advantages granted to annuity contracts, Congress "believe[d] that the use of deferred annuity contracts to meet long-term investment goals, such as income security, [was] still a worthy ideal. However, [Congress] believe[d] that their use for short-term investment and income tax deferral should be discouraged." 9 These provisions, then, are intended to serve as a disincentive to individuals using such plans as tax shelters exclusively for short-term purposes, while still providing tax benefits to policyholders using annuities in their intended and legitimate manner.

Additionally, TEFRA's general revenue objectives were a motivating factor behind the law's new treatment of annuity plans. The sections of TEFRA limiting beneficial tax treatment of insurance annuity contracts fall within the Act's revenue provisions. The goals of the revenue provisions include the raising of funds in an effort to narrow the budget deficits which had resulted from prior spending and tax policies, and the desire to increase tax equity by "scaling back or repealing those tax preferences which [were] no longer needed or which [could] no longer be justified in light of the present budgetary situation."10 The projected revenue effects of the legislative enactments concerning the tax treatment of insurance annuities reflect

7. Id., reprinted in 1982 U.S. Code Conc. \& AD. News at 1187.

8. Id., reprinted in 1982 U.S. CODE Cong. \& AD. NEws at 1187.

9. Id., reprinted in 1982 U.S. Code Cong. \& AD. News at 1187.

10. Id. at 97, reprinted in 1982 U.S. COde Cong. \& AD. News at 866. 
Congress' intent that TEFRA provisions dealing with annuity contracts serve as revenue-raising efforts. ${ }^{11}$

In accordance with the policy objectives of the TEFRA provisions limiting the beneficial tax treatment granted to holders of annuity contracts, the statutory changes are not intended to affect the tax treatment of amounts received as annuity payments after the annuity starting date. Rather, the Act seeks to preserve the tax benefits granted to insurance annuities used as longrange planning tools, but changes the effectiveness as short-term investment vehicles used to avoid ordinary tax treatment. TEFRA's two principal modifications of the tax treatment of annuity contracts relate to withdrawals of funds made before the starting date specified in the contract. First, the Act provides that partial surrenders or cash withdrawals prior to the annuity starting date are treated as income to the extent that the cash value of the contract exceeds the investment in the contract. ${ }^{12}$ The Act also imposes a penalty on certain distributions made from an annuity contract. ${ }^{13}$

\section{B. TEFRA Changes in Section 72}

Section 72(e) of the Internal Revenue Code deals with the taxation of withdrawals from the policies and was amended under TEFRA to eliminate the preferential tax treatment of preannuity payments afforded to policyholders under prior law. The Act reverses pre-TEFRA law regarding early withdrawals and generally provides that amounts received before the annuity starting date will be treated first as withdrawals of income earned on the investment to the extent of such income. Any amount received before the annuity starting date which falls within the ambit of section 72(e) is "included in gross income to the extent allocable to income on the contract." 14 To the extent the amount received is allocable to the investment in the contract, it is not included in gross income. ${ }^{15}$

"Income on the contract" is computed by starting with the cash value of the contract (which includes all the premiums paid and the accumulated interest credited to the policyholder's account, without deducting any surrender charge assessed by the company) immediately prior to the time the amount is to be received. The cash value is then reduced by the investment in the contract to arrive at the "income on the contract." 16 If no previous withdrawals have been made, a taxpayer can easily obtain this figure by calculating the accumulated interest which the insurance company has credited to his account and on which no tax has been paid.

11. See H.R. Conf. REP. No. 760, 97th Cong., 2d Sess. 691, reprinted in 1982 U.S. Code Conc. \& AD. News 1190, 1454 (life insurance and annuity provisions of TEFRA were expected to bring in $\$ 1.9$ billion in 1983 , increasing to $\$ 3.4$ billion in 1987 ).

12. I.R.C. \& 72(e)(3)(A) (Lawyers Co-op. 1984).

13. Id. \& 72(q)(amended 1984).

14. Id. $\& 72(\mathrm{e})(2)(\mathrm{B})(\mathrm{i})$.

15. Id. $872(\mathrm{e})(2)(\mathrm{B})(\mathrm{ii})$.

16. Id. \&72(e)(3)(A). 
"Investment in the contract" is calculated by subtracting from the "aggregate amount of premiums or other consideration paid for the contract" the "aggregate amount received under the contract before" the present disbursement, "to the extent that such amount was excludable from gross income under" current or prior income tax law. ${ }^{17}$ Investment in the contract, in simpler terms, can be viewed as the policyholder's net cost of the contract, as long as the amounts previously received as income on the contract are not subtracted from the total amount that the policyholder has paid.

Thus, a premature distribution of less than the "income on the contract" (or cash value minus investment in the contract) is considered income. ${ }^{18} \mathrm{~A}$ premature distribution in excess of the "income on the contract" is considered a tax-free return on investment. ${ }^{19}$ Simply put, withdrawals are allocated first to income and then to investment.

The Act provides that loans or pledges made against an annuity contract are treated the same as cash withdrawals for purposes of the new rule. ${ }^{20}$ Such amounts, then, are subject to the above provisions and are taxable as ordinary income to the extent allocated to income on the contract.

TEFRA also assesses a penalty on certain distributions from an annuity contract. Section $72(q)$ of the Code, as revised, imposes a $5 \%$ penalty on certain premature distributions from annuity contracts, but only with respect to earnings attributable to premiums paid after August 1982. This penalty is assessed on the total amount withdrawn to the extent that such amount is includable in income ${ }^{21}$ and is properly allocable to any investment in the contract made during the ten year period ending on the date such amount was received by the taxpayer. ${ }^{22}$ For these purposes, a first-in, first-out system of allocation is used. In other words, the amount includable in income for section 72(q) purposes is allocated to the earliest premium paid for the annuity to which includable income has not been previously assigned.23 Thus, only income which is derived from premiums paid in the last ten years is penalized. ${ }^{24}$ No penalty is imposed on the withdrawal of funds allocated to investment in the contract.

To illustrate these provisions, assume that an annual premium annuity contract is purchased after 1982. Further assume that after twelve years of paying annual premiums, the first year's premium has accrued earnings of $\$ 2,000$, the second year's $\$ 1,800$, and the third year's $\$ 1,500$. If the annuitant then decides to make an early withdrawal of $\$ 5,000$ from his policy, the entire $\$ 5,000$ will be included as income under section $72(\mathrm{e})$ since income on the contract exceeds the amount withdrawn. For section $72(q)$ purposes,

\footnotetext{
17. Id. \& 72(e)(6).

18. Id. \& $72(\mathrm{e})(3)(\mathrm{A})$.

19. See id. $872(\mathrm{e})(3)(\mathrm{B})$.

20. See id. \& 72(e)(4)(A).

21. See supra text accompanying note $\mathbf{1 6}$.

22. I.R.C. \& 72(q)(1)(A) (Lawyers Co-op. 1984)(amended 1984).

23. Id. $872(\mathrm{q})(1)(\mathrm{B})$ (amended 1984).

24. Id. $82(\mathrm{q})(1)(\mathrm{A})$ (amended 1984).
} 
however, only amounts withdrawn before ten years have elapsed will be penalized. Since section $72(q)$ uses a first-in, first-out allocation basis, the first $\$ 3,800$ is exempt from the penalty tax. Only $\$ 1,200$ of the total $\$ 5,000$ withdrawal is considered withdrawn from income earned within the last ten years, and is thus subject to the $5 \%$ penalty tax.

The new law expressly provides for several exceptions to the penalty provisions. No penalty is assessed on distributions made once the policyholder reaches age fifty-nine and one-half years, distributions attributable to the policyholder's becoming disabled, distributions made to a beneficiary after the death of the policyholder, or distributions from qualifying pension plans. In addition, the penalty does not apply to a payment which is one of a series of substantially equal periodic payments made for life or for at least five years. ${ }^{25}$

TEFRA has effectively modified the Code provisions regarding the taxation of early withdrawals from annuity contracts to discourage the use of such plans as short-term investment vehicles, while still providing a tax incentive to those individuals wishing to use annuities for the legitimate purpose of ensuring long-range income security. The law, in general, has retained the favorable tax benefits conferred on monies invested in annuity contracts and has limited the permissiveness of tax treatment only with regard to those payments which constitute early withdrawals. By characterizing the initial premature withdrawals as income which is fully taxable, the Act currently exacts a charge for the superior liquidity of traditional annuity policies. The additional $5 \%$ penalty serves as a further disincentive to shortterm policy investors while being reasonable enough to allow the investor access to his investment for an individual emergency which would not qualify as one of the statutory exceptions. The five statutory exceptions to the penalty can hardly be faulted as constituting potential bases for circumventing the general rule; the number of investors who qualify for such exemptions is likely to be de minimis. Moreover, the stated exemptions represent understandable and compassionate congressional policies and priorities for extreme cases of human hardship.

\section{IV}

\section{Limitations on the EfFectiveness of the TEFRA Changes}

Section 72(e)(5) provides for the retention of pre-TEFRA rules under existing contracts ${ }^{26}$ and under life insurance and endowment contracts. ${ }^{27}$ The subsection dealing with life insurance and endowment contracts, however, imposes no ironclad rule regarding the treatment of such plans, since Congress has stipulated that pre-TEFRA treatment will apply "[e]xcept to the extent prescribed by the Secretary by regulations."28 Section

25. Id. \& 72(q)(2).

26. Id. $872(\mathrm{e})(5)(\mathrm{B})$.

27. Id. $\$ 72(\mathrm{e})(5)(\mathrm{C})$.

28. Id. 
$72(e)(5)(C)$, then, leaves open the possibility that the TEFRA restrictions on annuities can be avoided by prudent investors who hold tax beneficial life insurance policies rather than annuity contracts. This section examines the mechanics of universal life policies and inquires whether, by investing in such plans, the limitations imposed by TEFRA can successfully be avoided.

\section{A. The Mechanics of Universal Life Policies}

A universal life insurance policy, also known as a flexible premium life or adjustable life insurance contract, is a single contract which reflects a composite of a renewable term policy and annuity or accumulation account. Once the policy is activated, the term policy and the accumulation account each operate independently. Universal life insurance policies are notable primarily for their flexibility; the amounts and frequency of the premium payments are determined by the policyholder and may be increased or decreased at any time. He or she may switch back and forth between whole life and term coverage, and may increase or decrease the amount of coverage as needed. The policyholder is at liberty to make unscheduled premium payments at any time, and can specify the policy's maturity date while retaining the right to change the date at will. ${ }^{29}$

In addition to the benefits of universal life insurance policies which flow directly from their flexibility, section 101 grants these policies the same preferential tax treatment traditionally afforded to life insurance arrangements. Under section 101(a), earnings accumulate tax free and death proceeds, which reflect both the true insurance benefit and the cash value of the contract including the policyholder's investment and all interest credited to his account, are passed to the beneficiary income tax free. Investments also earn competitive interest and rates of return.

\section{B. Past Abuses of Universal Life}

The flexibility of premium payments under universal life plans has often had the effect of allowing the policies to turn into nothing but disguised savings plans which, unlike other savings plans, qualified under section 101(a) for an income exemption for the beneficiary upon the death of the policyholder. Decisions interpreting section $101(\mathrm{a})$ have required the contract to possess an element of insurance risk to qualify as life insurance. ${ }^{30}$ Congress, aware of the potential abuses that flexible premium life insurance contracts made available to investment oriented policyholders and cognizant of their relatively increased desirability in light of the changes in TEFRA tax treatment of annuities, sought to limit the availability of tax benefits associated with such contracts. The legislature strove to find an appropriate compromise between its interest in limiting the abusive use of universal life insurance contracts and its general belief that "flexible premium life

29. E.g., I.R.S. Letter Ruling 81-16073 (Nov. 24, 1982).

30. See infra text accompanying note 63 . 
insurance contracts should have the same tax treatment as traditional levelpremium whole life insurance contracts if they are substantially comparable to traditional contracts." 31 As discussed in the next section, TEFRA retained the provisions granting favorable tax treatment to insurance policies, but established guidelines for treating universal life policies as tax-free life insurance arrangements. These provisions essentially require the policyholder to diversify a risk through the insurance company's other policyholders in order for the policy to fall under the statute.

\section{TEFRA Treatment of Universal Life}

TEFRA provides that in order to be treated as a life insurance policy, a flexible premium life insurance plan must at all times over the duration of the contract satisfy one of two alternate requirements: (1) the sum of premiums paid under the contract at any time cannot exceed a specially computed "guideline premium limitation," 32 and any amount payable on the death of the insured cannot be less than the "applicable percentage" of the contract's cash value as of the date of death, ${ }^{33}$ or (2) the cash value must not exceed the "net single premium" for the death benefit at such time. ${ }^{34}$

For purposes of satisfying the first of the two alternate tests provided by the Act, the "guideline premium limitation" 35 refers to the greater of "(i) the guideline single premium, or (ii) the sum of the guideline level premiums to such date." 36 The "guideline single premium" is defined as a single premium amount necessary to fund the contract (based on the contract's mortality assumptions and interest at the greater of a rate of $6 \%$ or the rate guaranteed by the contract). ${ }^{37}$ The "guideline level premium" is calculated as the sum of level annual payments over the life of the contract (but not less than twenty years from the issue date, or not later than age ninety-five, whichever is earlier). This amount is to be computed in the same way as for the guideline single premium, except that the interest rate used in the calculations for the guideline level premium cannot be less than $4 \% .^{38}$

The term "applicable percentage" 39 requires that the death benefit under the universal life contract must constitute $140 \%$ of the cash value until the insured reaches age forty. The applicable percentage is thereafter reduced by $1 \%$ for each year after forty, but does not drop below $105 \% .{ }^{40}$ Section 101 also articulates computational rules for the guideline premiums, which must be used when making the above calculations to determine whether the tax

31. S. Rep. No. 494, 97th Cong., 2d Sess. 350, 352, reprinted in 1982 U.S. Code Cong. \& Ad. News 781, 1087.

32. I.R.C. \& $101(f)(1)(A)(\mathrm{i})$ (Lawyers Co-op. 1984)(amended 1984).

33. Id. \& $101(\mathrm{f})(\mathrm{I})(\mathrm{A})$ (ii)(amended 1984).

34. Id. \& $101(\mathrm{f})(1)(\mathrm{B})$ (amended 1984).

35. Id. $101(\mathrm{f})(2)(\mathrm{A})$.

36. Id. \& $101(\mathrm{f})(2)(\mathrm{A})(\mathrm{i})$-(ii).

37. Id \& 101 (f)(2)(B).

38. Id. \& $101(\mathrm{f})(2)(\mathrm{C})$.

39. See id. $\$ 101(\mathrm{f})(1)(\mathrm{A})(\mathrm{ii})$ (amended 1984).

40. Id. $8101(\mathrm{f})(3)(\mathrm{C})$. 
benefit requirements have been satisfied. ${ }^{41}$ First, the net amount at risk (the excess of the amount payable at death, without regard to qualified additional benefits, over the cash value) assumed to exist at any time cannot exceed the net amount at risk existing when the contract was issued.42 Second, the maturity date of the contract is the latest maturity date permitted under the contract, but this date cannot fall less than twenty years after the contract is issued, or age ninety-five if earlier. ${ }^{43}$ Third, the amount of any endowment benefit (the benefit payable if the insured survives to the contract's maturity date) cannot exceed the smallest death benefit at any time, from the issue date to the maturity date, that was used as the future contractual benefit assumed in computing the guideline premiums. ${ }^{44}$

The rules also require that adjustments be made to reflect future changes in benefits. If, after a guideline single premium or a guideline level premium is calculated, any future or other qualified additional benefits are changed or added on any subsequent date, the guideline premium limitation measures must be modified to reflect the change. ${ }^{45}$

For purposes of satisfying the second alternative test for qualification for section 101(a) tax exclusion, ${ }^{46}$ the cash value of a flexible premium life insurance contract may not exceed the "net single premium" for death benefits (determined without regard to any qualified additional benefits) at such time. ${ }^{47}$ Under the cash value test, the net single premium must be computed using the most recent mortality table allowed under all state laws on the date of issuance, and the assumed interest must be based on the greater of $4 \%$ (3\% for contracts issued before July 1,1983$)$ or the minimum rate or rates guaranteed upon issuance of the contract. ${ }^{48}$ The computation rules articulated with respect to guideline single premiums and guideline level premiums ${ }^{49}$ are also applicable to net single premiums, except that the maturity date referred to in section $101(\mathrm{f})(2)(\mathrm{D})$ (ii) shall not be earlier than age ninety-five. ${ }^{50}$

The conditions under which a policyholder can use flexible premium life insurance plans to obtain section 101(a) exemption status are admittedly circumscribed by the requirements articulated in section 101(f). These statutory requisites, however, do not foreclose the possibility that investors can fashion their policies so as to satisfy the tests articulated under section $101(f)$, thereby invoking the tax benefits provided by section 101(a), while simultaneously accumulating a substantial cash build-up in the policy. The rules under section 101 (f), in general terms, require that the total sum of the

\footnotetext{
41. See id. $\$ 101(\mathrm{f})(2)(\mathrm{D})$.

42. Id. \& $101(\mathrm{f})(2)(\mathrm{D})(\mathrm{i})$.

43. Id. $\$ 101(\mathrm{f})(2)(\mathrm{D})$ (ii).

44. Id. \& $101(\mathrm{f})(2)(\mathrm{D})$ (iii).

45. Id. \& $101(\mathrm{f})(2)(\mathrm{E})$

46. See supra text accompanying note 34 .

47. $1 d$.

48. I.R.C. \& $101(\mathrm{f})(3)$ (G)(i)(ii) (Lawyers Co-op. 1984).

49. See id. \& $101(\mathrm{f})(2)(\mathrm{D})$ (i)-(iii).

50. Id \& $101(\mathrm{f})(3)(\mathrm{G})$ (iii).
} 
premiums be limited with respect to the projected death benefits, thereby ensuring that the contract will offer at least a minimum of pure insurance protection at all times. Through this provision, Congress sought to reinstate the historic balance between risk-shifting and tax-sheltered investment elements. Thus, a policyholder who wishes to build up the cash value of his policy can achieve this result to the extent that he is willing and able to expand his pure insurance protection. Despite this limitation, the section 101(f) requirements seem flexible enough that a prudent policyholder can substantially add funds to his accumulation account as long as he increases the insurance aspect of his policy. Therefore, although investors interested in the short-term tax-favored benefits of universal life policies will find it more difficult to qualify for section 101 (a) treatment than they did under the preTEFRA provisions, it is by no means an impossible or unduly burdensome task, and careful planning, along with the minimum required increase in the total amount invested, can result in numerous short-term tax advantages.

The new section 101(f) definitional requirements are aimed primarily at preventing excessive investment in plans which qualify for section 101 (a) treatment but in reality are an accumulation of savings with little or no insurance element. Section 101 (f), however, does not address to what extent premature withdrawals from the so-called accumulation account may be given the tax favorable treatment formerly given annuities and presently given withdrawals from universal life under section $72(e)(5)(C)$. Although it is apparent that abusive early withdrawals previously could be made from universal life plans, this aspect did not appear to be as salient until TEFRA imposed restrictions on early withdrawals from annuities. The determination of whether a given accumulation account qualifies for section 72(e)(5)(C) treatment rests on whether the amount withdrawn comes from a unitary life insurance contract. If so, then by its terms, section $72(e)(5)(C)$ stipulates that it would receive the favorable treatment provided by the pre-TEFRA section 72. If the account is separable from the life insurance contract, however, then early withdrawals may be taxed under standard section 72(e) and (q) provisions or may be taxable as ordinary interest income.

The Code's ambiguity could be clarified at any time if the IRS were to take advantage of the invitation extended under section $72(e)(5)(C)$ to prescribe regulations which would apply the penalty provisions of section $72(\mathrm{e})$ to section 101 policies. Notwithstanding this invitation and section $101(f)(3)(A), 51$ the Code does not give any guidance on the issue of separability. Commentators have also avoided the question, merely stating that accumulation accounts do qualify for favorable treatment, but failing to say why or to what extent. ${ }^{52}$ The remainder of this note argues that separability is still an unresolved question, but that the Code is porous

51. See supra note 28 and accompanying text.

52. See, e.g., Chiechi \& Adney, An Analysis of the Effects of the Life Insurance and Annuity Provisions of TEFRA, 57 J. TAX'N 338, 340-41 (1982); Hira, TEFRA Restrictions on Annuities: A Way to Avoid Them, 62 TAXES 10, 11-12 (1984). 
enough to allow many different types of accumulation accounts and early withdrawals to qualify for such favorable treatment that the effectiveness of the section 72(e) changes is seriously compromised.

1. Section $101(f)(3)(A)$ and Case Law. The plain language of section 101 indicates that the characterization of a policy for purposes of determining whether tax preferential treatment will be afforded to a given policy turns on an application of state law. The Code provides that

[t]he terms "flexible premium life insurance contract" and "contract" mean a life insurance contract (including any qualified additional benefits) which provides for the payment of one or more premiums which are not fixed by the insurer as to both timing and amount. Such terms do not include that portion of any contract which is treated under State law as providing any annuity benefit other than as a settlement option. ${ }^{53}$

Thus, the treatment of a given policy under applicable state law will be determinative for section 101 purposes, and the factors state courts have used to distinguish annuity contracts from insurance contracts must be examined in order to predict how such policies are to be treated under the Code.

According to the Conference Committee report, if a flexible premium contract is treated under state law as a single, integrated contract, it will be treated as a single contract for section 101 purposes. ${ }^{54}$ Courts have applied traditional contract analysis to insurance policies and accordingly have held that insurance purchasing is governed by contract law principles and that such policies are to be tested by principles applicable to the making of contracts in general. ${ }^{55}$ Thus, it seems relatively easy for an issuing company or a prospective policyholder effectively to mandate a judicial interpretation of a policy as a single contract by sufficiently linking the accumulation account to the policy's pure insurance protection in contract terms. In this way, the accumulation account will ride on the coattails of the insurance portion of the agreement, and the entire policy will fall within the protective ambit of section 101 .

The only remaining question is whether, given the apparent abuses of such policies, their potential for contravening the legislative intent, and their similarity to annuities, the courts are likely to interpret such a policy, with its accumulation account, as universal life insurance. The statutory language seems to compel such a result.56 Moreover, the case law, which is rich in conflicts among parties over whether a given arrangement constitutes an insurance or annuity contract, indicates that universal life policies, along with their accompanying accumulation accounts, are likely to be interpreted as insurance for purposes of section 101 coverage. ${ }^{57}$

53. I.R.C. \&101(f)(3)(A) (Lawyers Co-op. 1984).

54. H.R. Conf. ReP. No. 760, 97th Cong., 2d Sess. at 649, reprinted in 1982 U.S. Code Cong. \& AD. News at 1419.

55. See, e.g., Roscoe v. Bankers Life Ins. Co., 22 Ariz. App. 282, 284, 526 P.2d 1080, 1082 (1974); Little v. Barry, 417 A.2d 966, 967 n.2 (D.C. 1980); Woseca Mut. Ins. Co. v. Noska, 331 N.W.2d 917, 926 (Minn. 1983).

56. I.R.C. $\$ 72(e)(5)$ (C) (Lawyers Co-op. 1984).

57. See infra notes 58-66 and accompanying text. 
State courts have articulated numerous factors which they have used in determining whether a given agreement constitutes an insurance or an annuity contract. There appears to be a general judicial consensus "that contracts for annuities differ from life insurance policies," 58 although courts often acknowledge that the two plans are, in effect, opposites, ${ }^{59}$ or at least distinctly different.60 One factor which is characteristic of all annuity contracts is the existence of an agreement by the company to pay fixed periodic payments, either for life or for a term of years, to the policyholder. ${ }^{61}$ Insurance policies, alternatively, are not characterized by the payment of fixed periodic payments. One court has summarized the commonly accepted notion of life insurance: "It is an agreement wherein the insured makes a payment or, more usually, agrees to make periodic payments . . . to an insurance company, in return for which, upon his death, it agrees to pay to those persons whom he designates as beneficiaries a definite sum of money "62

The notion of risk inherent in both insurance and annuity contracts is of central importance in distinguishing the two. Each type of policy presents a type of risk, but " $[\mathrm{t}]$ he risks assumed under life insurance policies and under annuity contracts are diametric opposites." 63 One court has specified that

for a contract to be one of insurance it is essential that there be hazard and a shifting of the incidence [of risk]. If there is no risk, or if there be one and it is not shifted to another or others [i.e., shifted away from the policyholder], there can be no insurance. ${ }^{64}$

Corbin is in substantial agreement, and expands on this notion: "In life insurance, the insured wins his wager, and the insurer loses, if death occurs soon and before many premiums have been paid . . . . In annuity cases, the

58. Corporation Comm'n v. Equitable Life Assurance Soc'y of the United States, 73 Ariz. 171, 175, 239 P.2d 360, 362 (1951); see also SEC v. Variable Annuity Life Ins. Co., 359 U.S. 65, 71 (1959).

59. See, e.g., In re Estate of Newton, 177 Misc. 877, 886, 32 N.Y.S.2d 473, 481 (1941), affd mem., 267 A.D. 913,48 N.Y.S.2d 332 (1944).

60. See, e.g., Prudential Ins. Co. of Am. v. Howell, 29 N.J. 116, 121, 148 A.2d 145, 148 (1959); Bayer's Estate, 345 Pa. 308, 311, 26 A.2d 202, 205 (1942).

61. See Cranley v. Schirmer, 27 Conn. Supp. 258, 263-64, 236 A.2d 332, 335 (1967); Wolfe v. Breman, 69 Ga. App. 813, 818, 26 S.E.2d 633, 637 (1943); In re Weill's Will, 113 Ind. App. 99, 10607, 45 N.E.2d 362, 365 (1942); In re Estate of Johnson, 238 Iowa 1221, 1226, 30 N.W.2d 164, 167 (1947); Northwestern Mut. Life Ins. Co. v. Murphy, 223 Iowa 333, 335, 271 N.W. 899, 900 (1937); Succession of Rabouin, 201 La. 227, 235, 9 So. 2d 529, 531 (1942); Everett v. Commissioner of Corps. \& Tax'n, 317 Mass. 612, 614, 59 N.E.2d 186, 187 (1945); Commissioner of Corps. \& Tax'n v. Hale, 315 Mass. 556, 558, 53 N.E.2d 675, 676 (1944); Gregg v. Commissioner of Corps. \& Tax'n, 315 Mass. 704, 707, 54 N.E.2d 169, 171 (1944); Dalton v. Florence Home for the Aged, 154 Neb. 735, 737, 49 N.W.2d 595, 597 (1951); Tobler v. Moncrief, 72 N.J. Super. 48, 51-52, 178 A.2d 105, 107 (1962); Moore v. O'Cheskey, 87 N.M. 66, 66-67, 529 P.2d 292, 292-93 (1974); Bronson v. Glander, 149 Ohio St. 57, 59, 77 N.E.2d 471, 472 (1948); McNally v. Evatt, 146 Ohio St. 443, 446, 66 N.E.2d 633, 635 (1946); In re Dwight's Estate, 389 Pa. 520, 525, 134 A.2d 45, 48 (1957); Hunter v. First Nat'l Exch. Bank, 198 Va. 637, 643-44, 96 S.E.2d 104, 108 (1957).

62. Dary v. Walsh, 132 Conn. 5, 12, 42 A.2d 366, 369 (1945), cited with approval in New Britain Nat'l Bank v. Life Ins. Co., 6 Conn. Cir. Ct. 674, 677-78, 305 A.2d 296, 298 (1972).

63. Prudential Ins. Co. of Am. v Howell, 29 N.J. 116, 121, 148 A.2d 145, 148; see also Corporation Comm'n v. Equitable Life Assurance Soc'y of the United States, 73 Ariz. 171, 179, 239 P.2d 360, 365; Cruthers v. Neeld, 14 N.J. 497, 505, 103 A.2d 153, 157-58 (1954).

64. Estate of Bart, 104 Cal. App. 2d 506, 508, 231 P.2d 876, 878 (1951). 
holder of the policy wins his wager, and the company loses, if the holder lives a long time . . . "65 The Supreme Court has also identified the element of risk-shifting as inherent in the distinction between insurance and annuity plans. ${ }^{66}$

Other courts have articulated the distinction between annuity and insurance policies not in terms of the type of risk inherent in each, but in terms of an investment as opposed to an indemnity. "[A]nnuities are not indemnities for death but are investments for life. They are designed as safeguards against misfortune and want during the life of the annuitant and are essential [sic] provisions for life and not provisions for death." 67 In short, insurance contracts provide against the contingency of death, while annuities with no indemnity feature are provisions for life. ${ }^{68}$ Federal courts, in their review of annuity and insurance policies, have found the same factors to be determinative in distinguishing between the two types of policies. ${ }^{69}$ The commentators are essentially in accord. ${ }^{70}$

When analyzing universal life insurance policies in light of the foregoing factors, it appears evident that such contractual arrangements are more closely akin to insurance policies than to traditional annuity plans. As indicated in the definition of universal life insurance articulated earlier, ${ }^{71}$ no fixed periodic payments are promised by the company to the insured. This element has consistently been held to be decisive in determining whether a given plan qualifies as an annuity. ${ }^{72}$ But universal policies, like life insurance plans generally, do require that the policyholder make periodic payments to the company, although section 101 (f) indicates that such payments "are not [to be] fixed by the insurer as to both timing and amount." 73 Furthermore, the understanding that the beneficiaries of the insured will receive a previously agreed-upon payment after the death of the policyholder is implicit in the basic premise of universal life plans, as in all life insurance policies. ${ }^{74}$

The nature of universal life insurance policies displays an inherent element of risk on the part of the insurer. As with all insurance policies, the company exposes itself to the risk that the policyholder will die before the

65. 3A A. Corbin, Corbin on Contracts \$ 731 (1960).

66. See Commissioner v. Le Gierse, 312 U.S. 531, 539 (1941).

67. Corporation Comm'n v. Equitable Life Assurance Soc'y of the United States, 73 Ariz. 171, 175-76, 239 P.2d 360, 362; see also Prudential Ins. Co. of Am. v. Howell, 29 N.J. 116, 121, 148 A.2d 145, 148; Daniel v. Life Ins. Co., 102 S.W.2d 256, 260 (Tex. Civ. App. 1937).

68. In re Estate of Sothern, 170 Misc. 805, 808-09, 14 N.Y.S.2d 509, 512 (1938).

69. See NLRB v. Rice Lake Creamery Co., 365 F.2d 888, 893 (D.C. Cir. 1966); Iglehart v. Commissioner, 174 F.2d 605, 606 (7th Cir. 1949); Bodine v. Commissioner, 103 F.2d 982, 984 (3d Cir. 1939); Old Colony Trust Co. v. Commissioner, 102 F.2d 380, 382 (1st Cir. 1939); Stowe Township v. Standard Life Ins. Co., 363 F. Supp. 341 , 343 (W.D. Pa. 1973); Silberman v. United States, 333 F. Supp. 1120,1126 (W.D. Pa. 1971).

70. See generally A. Corbin, supra note 65, $8731 ; 1$ J. Appleman \& J. Appleman, Insurance LaW and Practice $\$ 83$ (1981).

71. See supra text accompanying note 29.

72. See supra note 61 and accompanying text.

73. I.R.C. \& 101(f)(3)(A) (Lawyers Co-op. 1984).

74. See id. \&101(a)(1). 
payment of substantial premiums. Furthermore, the insurance amount test ${ }^{75}$ helps preserve this element of risk. The required benefit amount will be lower when the policyholder is young and there will be an escalation in the cost of the insurance as the risk of mortality becomes greater. Although the incidence of risk diminishes, this sliding scale approach is designed so that the actual risk coverage will be comparable to that provided by whole life insurance, which similarly decreases with time. This requirement also ensures that the policy will at all times provide a reasonable minimum amount of pure insurance protection throughout the duration of the policy. ${ }^{76}$

The other tests set forth in section $101(\mathrm{f})$ to determine whether section 101(a) treatment can be granted to a given universal life policy reinforce the proposition that such insurance plans will possess many of the attributes of more traditional insurance contracts. The guideline premium test ${ }^{77}$ provides for some equivalency between universal life and whole life policies. The guideline single premium ${ }^{78}$ and guideline level premium ${ }^{79}$ tests seek to ensure that a policyholder will not invest more in his universal life policy than he would have invested had he purchased a whole life insurance plan providing comparable benefits. Under the TEFRA restrictions, the guideline single premium is comparable to the premium required to fund single premium whole life, and the guideline level premium represents the cumulation of premiums that would have been paid into a traditional policy. By imposing this artificial ceiling on investment and by providing for a builtin, albeit diminishing, risk factor, TEFRA ensures that only a universal life policy which has sufficient attributes as an insurance policy will qualify as life insurance and receive tax-exempt status under section 101 (a).

An important consideration remains in determining whether universal life insurance policies will qualify for section 101(a) treatment. It is well settled that the incidence of taxation is governed by the substance rather than the form of a transaction. ${ }^{80}$ Thus, when a policy is scrutinized to determine its character for tax purposes, courts have consistently noted that "a label placed upon an agreement by the parties thereto need not be determinative of its character." 81 It has been considered an affirmative duty of the court to scrutinize the substance of agreements so as to "rest their applications upon the realities." 82

75. See supra notes $32-33$ and accompanying text.

76. S. ReP. No. 494, 97th Cong., 2d Sess. at 354, reprinted in 1982 U.S. Code Cong. \& AD. NEws at 1089 .

77. I.R.C. § $101(\mathrm{f})(2)$ (A) (Lawyers Co-op. 1984).

78. Id. \$101(f)(2)(B).

79. Id. \& $101(\mathrm{f})(2)(\mathrm{C})$.

80. See, e.g., Diedrich v. Commissioner, 457 U.S. 191, 195 (1982); Old Colony Trust Co. v. Commissioner, 279 U.S. 716, 729 (1929); TSN Liquidating Corp. v. United States, 624 F.2d 1328, 1331 (5th Cir. 1980).

81. Bodine v. Commissioner, 103 F.2d 982, 984 (3d Cir. 1939); see also Commissioner v. Meyer, 139 F.2d 256, 258 (6th Cir. 1943).

82. Commissioner v. Meyer, 199 F.2d 256, 258 (6th Cir. 1943). 
The courts' preoccupation with ascertaining the true nature of insurance policies stems from an overarching concern with congressional intent and a recognition that judicial interpretations should promote the legislative policies underlying the statutory language. ${ }^{83}$ The longstanding judicial practice of reviewing the substance of transactions in tax cases arose out of a desire to avoid subverting the purpose of the Code. ${ }^{84}$ The Supreme Court has shared this concern, noting that

[ $t$ ] he incidence of taxation depends upon the substance of a transaction. . . . The transaction must be viewed as a whole .... To permit the true nature of a transaction to be disguised by mere formalisms, which exist solely to alter tax liabilities, would seriously impair the effective administration of the tax policies of Congress. ${ }^{85}$

As discussed above, the TEFRA provisions in section 72 of the Code were designed to eliminate the incentive for short-term investors to use annuity contracts as a vehicle for tax evasion. Similarly, the amendments to section 101 are intended to avoid giving deferral and section 101 (a) benefits to what are essentially investment accounts, that is, accounts which lack significant risk shifting. If, as has been postulated, universal life insurance agreements are such that a policyholder can take advantage of the relative flexibility of such contracts (although some limits do exist ${ }^{86}$ ) while simultaneously falling within the section 101 (a) tax exemptions, he or she can, in effect, sidestep the section 72 restrictions and the accompanying legislative policy considerations. As long as the section $101(\mathrm{f})$ requirements are met, however, section $101(\mathrm{a})$ treatment will be granted. "The legal right of a taxpayer to decrease the amount of what otherwise would be his taxes, or altogether avoid them, by means which the law permits, cannot be doubted."87 Furthermore, "the existence of a tax benefit resulting from a transaction does not automatically make it a sham as long as the transaction is imbued with tax-independent considerations." 88 Clearly, tax-independent considerations existed in TEFRA's treatment of universal life policies, namely, Congress' desire to encourage traditional life insurance contracts as well as flexible premium life insurance plans that are substantially comparable to traditional contracts. ${ }^{89}$ Unfortunately, Congress seems to have failed in its efforts to eliminate the potential for the abuse of such policies as short-term tax shelters. Thus, section 101 universal life policies are still open to some of the abuses of preTEFRA section 72 , in that the policyholder may accumulate premiums and earnings in a sheltered account, then withdraw them tax free when a better opportunity presents itself.

83. See id. at 259.

84. Bercy Indus., Inc. v. Commissioner, 640 F.2d 1058, 1062 (9th Cir. 1981).

85. Commissioner v. Court Holding Co., 324 U.S. 331, 334 (1945).

86. See generally supra text accompanying notes 32-50.

87. Gregory v. Commissioner, 293 U.S. 465, 469 (1935).

88. Holladay v. Commissioner, 649 F.2d 1176, 1179 (5th Cir. 1981); see also Frank Lyon Co. v. United States, 435 U.S. 561, 583-84 (1978).

89. See S. Rep. No. 494, 97th Cong., 2d Sess. at 361, reprinted in 1982 U.S. Code Conc. \& Ad. News at 1096. 
2. Analogous Regulations. The question whether any specified policy combining an insurance element and a savings fund arrangement is to be viewed for tax purposes as a single insurance contract or is to be broken up into its component parts is an area ripe for administrative guidance. Congress extended an apparent invitation for the IRS to draft regulations in this area, ${ }^{90}$ ostensibly to protect against the abuses that the TEFRA changes in section 72 supposedly cured. Yet Treasury Regulations have not been promulgated in response to this invitation regarding private insurance policies. While, in the absence of regulations, case law provides the most authoritative guidelines, it would seem natural to argue by analogy from other parts of the Code and Regulations which definitively address this problem in other contexts.

a. Estate tax. Treasury Regulations for the estate tax deal directly with the question of combination plans. The applicable regulation provides explicit definitions for classification of a policy at the death of the policyholder:

A combination annuity contract and life insurance policy on the decedent's life . .
which matured during the decedent's lifetime so that there was no longer an insurance
element under the contract at the time of the decedent's death is subject to the
provisions of section 2039 (a) and (b). On the other hand, the treatment of a
combination annuity contract and life insurance policy on the decedent's life which did
not mature during the decedent's lifetime depends on the nature of the contract at the
time of the decedent's death. . . If the decedent dies before the reserve value equals
the death benefit, there is still an insurance element under the contract. The contract
is therefore considered, for estate tax purposes, to be an insurance policy . .
However, if the decedent dies after the reserve value equals the death benefit, there is
no longer an insurance element under the contract. The contract is therefore
considered to be a contract for an annuity or other payment ....91

In other words, for estate tax purposes, any contract which has an element of insurance in it qualifies as an insurance policy. The annuity or savings fund arrangement is ignored for purposes of the initial classification. Analogizing that regulation to the income tax treatment of annuity or savings fund arrangements in universal life policies seems logically compelling. Of course, the bare existence of any insurance element would not be sufficient to classify a policy as life insurance under section 101 , for section $101(f)$ requires more than a de minimis degree of risk. If a policy fulfills the statutorily mandated minimal risk requirements under section $101(f)$, the existence of insurance risk should, as in estate tax, qualify the plan as a single contract entirely under section 101. The accumulation account would therefore qualify for taxfavored treatment under section $72(\mathrm{e})(5)(C)$.

90. See I.R.C. \& 72(e)(5)(C) (Lawyers Co-op. 1984). Section 72(e)(5) exempts life insurance and endowment contracts from the stricter early withdrawal provisions imposed by TEFRA, subject to $872(e)(5)(C)$. Thus, if regulations were promulgated by the IRS imposing the stricter withdrawal provisions on life insurance and endowment contracts, they would not be overruled by any explicit provision of the Code. Section 101(f)(3)(A) does not, in any way, mandate the application of state law if that law would exempt the annuity or savings fund proceeds from income tax. Section $101(f)(3)(A)$ only explicitly prohibits exempting the savings fund or annuity account from income in the case of death of the policyholder. Presumably then, any Treasury Regulation subjecting an accumulation account to the new section 72(e) provisions would override state law, even if that state law viewed the policy as one contract.

91. Treas. Reg. 8 20.2039-1(d) (1976). 
As compelling as this argument may sound, the general rule is that estate and gift taxes and income taxes are not interpreted in pari materia, since their underlying purposes are frequently dissimilar.92 Predictably, the IRS has been quick to dismiss the validity of the analogy in this case and has found that Treasury Regulation section 20.2039-1(d) should be a definitional statement for estate tax only. The IRS argues that since life insurance proceeds are includable in the gross estate under section 2042 and annuities are includable under section 2039, "characterization of a policy as either a life insurance contract or as an annuity contract will not necessarily prevent the application of the estate tax." 93 The implication of this argument is that since the policy will be taxed under either section, it is merely an arbitrary administrative convenience to apply a bright-line rule. The IRS argument fails to consider that sections 2039 and 2042 are indeed different and that annuities are subject to many exemptions to which life insurance proceeds are not, ${ }^{94}$ indicating that there are some legitimate parallels between the estate and income tax schemes. Nonetheless, the similarities between parallel estate and income tax provisions are not given much weight in facilitating their interpretation.

b. Qualified pension plan regulations. Examining the tax treatment of combination annuity and life insurance plans purchased and distributed by qualified employee trusts and pension plans provides further insight. It is noted at the outset that the applicable sections, by their own terms, refer only to qualified employee plans. ${ }^{95}$ Once again, though, in the absence of any regulation or code section specifying treatment of universal life policies, analogous sections may receive close scrutiny from the courts.

The pertinent regulations provide that

(i) ... certain payments under employee plans are taxable under section $72 . \ldots$ For purposes of applying section 72 to [qualified employee trusts and plans] each separate program of the employer consisting of interrelated contributions and benefits shall be considered a single contract. Therefore, all distributions or payments . . . which are attributable to a separate program of interrelated contributions and benefits are considered as received under a single contract.

(ii) ... [R]etirement benefits and life insurance will be considered part of a single separate program of interrelated contributions and benefits to the extent they are provided under retirement income, endowment, or other contracts providing life insurance protection. ${ }^{96}$

92. See, e.g., Commissioner v. Wemyss, 324 U.S. 303, 306-07 (1945); Farid-es-Sultaneh v. Commissioner, 160 F.2d 812, 814-15 (2d Cir. 1947). In Wemyss, the Court, for gift tax purposes, interpreted "gifts" in its broadest and most comprehensive sense and found a gift even where consideration, in the form of detriment, had been given. The Court used an objective, external test to find a gift and refused to allow subjective donative intent to be determinative. For income tax purposes in Farid-es-Sultaneh, however, the court interpreted "gift" very narrowly and found no gift because there was no subjective donative intent, despite the fact that the consideration was not monetary or necessarily fair.

93. G.C.M. 38934 (July 9, 1982).

94. See Treas. Reg. $\$ 20.2039-1$ (b)-(d) (1976).

95. As defined by I.R.C. \& 401 (Lawyers Co-op. 1983 \& Supp. 1985).

96. Treas. Reg. \& 1.72-2(3)(i)-(ii) (1966). 
Here again, the effect of this regulation is to qualify all benefits of a policy as insurance proceeds as long as there is an element of insurance in the pension plan context. Analogous treatment of privately purchased policies would lead to treating any policy which qualified under the flexible life requirements of section $101(\mathrm{f})$ as a single contract and thus eligible for favorable section 72(e)(5)(C) tax treatment. As expected, the IRS has indicated that it does not concur in such a view and that these regulations should be strictly construed to apply only to the pension plan context. Moreover, the IRS argues that with qualified plans, section $72(\mathrm{~m})(3)(\mathrm{C})$ limits the section 101 exclusion upon death and therefore that it is not necessary in the pension area to separate a policy into its component parts. ${ }^{97}$ Section $72(\mathrm{~m})(3)(\mathrm{C})$, however, addresses only tax treatment at death and says nothing of early withdrawal from such plans. Arguably, therefore, a statute which makes special provisions for qualified plan participants only upon death should have no bearing on early withdrawal tax treatment and private annuity plans which parallel pension plans in these respects should receive analogous treatment.

As in the estate tax area, however, parallels between sections of the Code, in and of themselves, do not mandate an identical result. Moreover, courts are understandably hesitant to import substantive elements of other sections into an exclusion from income. Nonetheless, the analogous sections of the Code which allow plans combining insurance and other elements to be treated as insurance policies indicate that Congress and the IRS have been willing to classify many multifaceted plans as insurance in the name of administrative convenience while conceding the tax advantages such a classification inevitably spawns. This point, when considered in connection with the gaps contained in the Code which must be filled by contract law, might lead a court to the conclusion that early withdrawals from a carefully drafted life insurance policy containing a savings fund or annuity element must be excluded from income so long as it is a return of capital.

\section{$\mathrm{V}$ \\ Conclusion and Recommendations}

From the foregoing materials, it is clear that there are many different types of accumulation accounts within a universal life insurance policy which may qualify for section $72(e)(5)$ tax treatment. Although an increase in the insurance protection is required to bolster the amount that may be withdrawn from the accumulation account, it is still likely that such an account could be very similar to a regular savings account or a pre-TEFRA annuity contract. Congress' original intent to prevent long-term investment vehicles from being used as short-term tax shelters may once again be circumvented.

The courts, as a result, are likely to feel somewhat uncomfortable with enforcement of the TEFRA provisions in such a way as to serve the legislative intent in only a very minimal way. In consideration of the previous materials,

97. G.C.M. 39022 (March 31, 1983); G.C.M. 38934 (July 9, 1982). 
though, the present Code and Regulations leave the judiciary little choice. To effect Congress' purposes, the courts may look toward the Code's "escape hatch" provision which indicates that regulations may be prescribed by the Secretary ${ }^{98}$ to bring accumulation accounts within section 72(e)(2) or other general income provisions. This solution could be easily promulgated by the IRS and appears to be the most expeditious method to effectuate congressional intent.

98. I.R.C. \& 72(e)(5)(C) (Lawyers Co-op. 1984). 
